\title{
HAK KEPERDATAAN ANAK LUAR KAWIN DALAM PERSPEKTIF ILMU HUKUM BERPARADIGMA PANCASILA
}

\author{
B. Resti Nurhayati \\ Fakultas Hukum dan Komunikasi Universitas Katolik Soegijapranata Semarang \\ Email : bernadeta resti@yahoo.com/resti@unika.ac.id
}

\begin{abstract}
ABSTRAK
Anak adalah generasi penerus cita-cita bangsa. Di tangan merekalah kehidupan bangsa dan Negara kita titipkan. Namun dalam fakta sehari-hari, kehidupan seorang anak tidaklah selalu mudah, karena masyarakat bahkan hukum mendiskriminasikan anak berdasarkan ukuran yang dibuat oleh masyarakat maupun oleh hukum. Anak dibedakan menjadi anak sah dan anak luar kawin. Berdasarkan pembedaan tersebut, anak diperlakuan secara berbeda oleh masyarakat dan hukum.

Tulisan ini bermaksud untuk menguraikan bahwa status hubungan hukum yang telah menyebabkan seorang anak dilahirkan ke dunia mestinya bukanlah satu-satunya ukuran untuk memberikan hak keperdataan bagi seorang anak. Metode yang digunakan adalah metode kualitatif, dengan menganalisis persoalan perlindungan anak luar kawin mendasarkan pada paradigma Pancasila.

Berdasarkan analisa ditemukan bahwa setiap anak berhak atas perlindungan hukum yang layak untuk mendapatkan pemeliharaan dan pendidikan, berhak untuk tumbuh kembang sebagaimana mestinya, serta mendapatkan hak-hak lain yang perlu untuk mendukung perkembangan jiwa raganya.
\end{abstract}

Kata kunci: Anak Luar Kawin, Hak Keperdataan Anak, Paradigma Pancasila.

\section{ABSTRACT}

Children are the generation continuing the ideals of a nation. In the hands of children, the life of a nation and state is relied on. However, in the fact of everyday life, children's life is not always easy because society and law discriminate children based on the standards made by public or law. Children are divided into legitimate children and illegitimate children born out of wedlock. Based on this distinction, children are treated differently by society and law.

This paper aims to outline that the marital status of biological parents should not the only measure to provide legal protection - especially with regard to the civil rights of a child. The method used was a qualitative method, by analyzing the issue of the protection to children born out of wedlock based on the provisions of the 1945 Constitution, child rights, and the national philosophy of Pancasila.

Based on the analysis, it was found that every child is entitled to adequate legal protection to get maintenance and education, to grow and develop properly, and to get other rights required to support his/ her physical and spiritual development.

Keywords: child born out wedlock, the civil rights of a child, Pancasila paradigm 


\section{Pendahuluan}

Anak adalah potensi dan penerus cita-cita bangsa. Pernyataan ini menggambarkan betapa pentingnya anak bagi kehidupan bangsa dan negara. Anak-anaklah yang suatu saat nanti memimpin bangsa dan negara. Demikian pentingnya anak dalam kehidupan berbangsa dan bernegara, sehingga orangtua, keluarga, masyarakat dan negara perlu memperhatikan dan memberikan perlindungan untuk hidup, tumbuh kembang anak secara wajar, serta mendapatkan perlindungan dari tindak kekerasan dan diskriminasi, agar mereka mencapai kedewasaan jiwa raga mereka secara sempurna.

Dalam kehidupan sehari-hari, masyarakat membedakan antara anak sah dan anak luar kawin. Hal ini terbukti dengan adanya beberapa istilah untuk menyebut anak luar kawin, seperti: "anak haram jadah", "anak kowar", "anak kampang”, "anak astral" dan sebagainya. Pembedaan atau diskriminasi ini dikenal pula dalam sistem hukum. Hukum membedakan anak menjadi "anak sah" dan "anak luar kawin". Diskriminasi, baik secara sosial kemasyarakatan maupun secara normatif, menimbulkan beban psikologis bagi anak yang berdampak terhadap perkembangan kehidupan selanjutnya.

Di dalam Kitab Undang-Undang Hukum Perdata (KUHPerdata), definisi tentang anak sah ditemukan dalam Pasal 250 KUHPerdata sebagai berikut: "Tiap-tiap anak yang dilahirkan atau ditumbuhkan sepanjang perkawinan, memperoleh si suami sebagai bapaknya". Seorang anak "dianggap" sebagai "anak sah" bila dilahirkan atau ditumbuhkan sepanjang perkawinan. Anak tersebut memiliki bapak suami dari ibunya, yang telah terikat secara resmi dalam perkawinan yang sah. Dengan demikian anak-anak yang tidak dilahirkan di dalam sebuah perkawinan yang sah atau bukan sebagai akibat ikatan perkawinan yang sah, maka anak-anak yang demikian "dianggap" sebagai "anak luar kawin".

Kewajiban bapak dan ibu terhadap anak-anak mereka menurut Pasal 298 ayat (2) KUHPerdata adalah memelihara dan mendidik sekalian anak mereka yang belum dewasa. Kehilangan hak untuk memangku kekuasaan-orangtua atau untuk menjadi wali tak membebaskan mereka dari kewajiban memberi tunjangantunjangan dalam keseimbangan dengan pendapatan mereka, guna membiayai pemeliharaan dan pendidikan itu. KUHPerdata tidak menyebutkan secara khusus, siapa (anak yang bagaimanakah) yang memiliki hak atas pemeliharaan dan pendidikan sebagaimana dimaksudkan dalam Pasal 298 ayat (2) KUHPerdata ini. Tetapi dalam konteks KUHPerdata, anak luar kawin karena tidak memiliki hubungan keperdataan dengan siapapun (baca Pasal 280 KUHPerdata) - termasuk dengan bapak biologis dan ibu yang melahirkannya - maka ketentuan Pasal 298 ayat (2) tersebut dapat diartikan bahwa hak pemeliharaan dan pendidikan hanya dimiliki oleh anak sah yang belum dewasa.

Dalam versi undang-undang asli Indonesia, Pasal 42 Undang-Undang Nomor 1 tahun 1974 tentang Perkawinan secara tegas menyebutkan: "Anak yang sah adalah anak yang dilahirkan dalam atau sebagai akibat perkawinan yang sah". 
Berdasarkan ketentuan tersebut dapat diartikan bahwa Undangundang Perkawinan membedakan anak menjadi "anak sah" dan "anak luar kawin". Perbedaan status ini menyebabkan hak anak-anak tersebut berbeda.

Dalam persoalan hubungan keperdataan anak luar kawin, Undang-Undang Nomor 1 Tahun 1974 tentang Perkawinan menganut prinsip yang berbeda dengan KUHPerdata. Menurut UndangUndang Perkawinan, anak luar kawin mempunyai hubungan keperdataan dengan ibunya dan keluarga ibunya. Terhadap Pasal 43 Undang-Undang Perkawinan telah dilakukan amandemen berdasarkan Keputusan Mahkamah Konstitusi Nomor 46/PUU-VIII/2010, sehingga Pasal 43 ayat (1) Undang-Undang Perkawinan harus dibaca:

Anak yang dilahirkan di luar perkawinan mempunyai hubungan perdata dengan ibunya dan keluarga ibunya serta dengan lakilaki sebagai bapaknya yang dapat dibuktikan berdasarkan ilmu pengetahuan dan teknologi dan/atau alat bukti lain menurut hukum mempunyai hubungan darah, termasuk hubungan perdata dengan keluarga bapaknya.

Hak atas pemeliharaan dan pendidikan serta hak waris merupakan inti dari hak keperdataan yang semestinya dapat dinikmati oleh setiap anak sah maupun luar kawin. Meskipun telah dilakukan amandemen, dalam praktek tidak mudah bagi anak luar kawin untuk mendapatkan hak keperdataan dari bapak biologisnya. Salah satu kasus yang menyita perhatian masyarakat Indonesia adalah gugatan pengakuan hak keperdataan anak bernama MIR yang diajukan oleh ibunya (MM) di Pengadilan Agama Jakarta Selatan. Hakim pengadilan tingkat pertama hanya mengabulkan gugatan bahwa anak Penggugat yang bernama MIR adalah anak biologis dari suami siri Penggugat, namun tidak mengabulkan gugatan adanya hubungan keperdataan antara si anak dengan bapak biologisnya. Keputusan Pengadilan Agama ini tidak sejalan dengan Keputusan Mahkamah Konstisi yang telah merevisi Pasal 43 ayat (1) Undang-undang Perkawinan yang pada intinya memberikan hak kepada anak yang lahir dari perkawinan siri untuk memiliki hubungan keperdataan dengan bapaknya dan keluarga bapaknya sepanjang dapat dibuktikan berdasarkan ilmu pengetahuan dan teknologi. Ditolaknya gugatan tersebut membuktikan bahwa tidak mudah bagi anak luar kawin untuk menggugat hak keperdataannya.

Dalam sistem hukum Indonesia, terdapat Pancasila sebagai dasar Negara Indonesia. Pancasila menjadi sumber dari segala sumber hukum di Indonesia. Dengan demikian seharusnya Pancasila menjadi jiwa dan mewarnai setiap hukum yang berlaku di Indonesia. Mengutip pandangan Noor MS. Bakry, bahwa dalam sila kemanusiaan yang adil dan beradab mewajibkan Negara untuk menghormati martabat dan hak-hak asasi manusia termasuk kebebasannya. (Bakry, Noor MS., 1994: 74). Berdasarkan pandangan tersebut, maka sudah seharusnyalah kita sebagai bagian dari bangsa Indonesia mengakui hak-hak asasi manusia termasuk kebebasannya, mengakui persamaan derajat manusia di hadapan hukum tanpa 
mendiskriminasikan manusia satu terhadap yang lainnya. Tidak sepantutnyalah terjadi kekerasan dan diskriminasi, termasuk perlakuan diskriminasi terhadap anak-anak yang dilahirkan di luar perkawinan. Oleh karena itu penulis tertarik untuk mengkaji perlindungan hak keperdataan anak luar kawin dalam pandangan paradigma Pancasila.

\section{Permasalahan}

Berdasarkan uraian tersebut di atas dapat ditarik permasalahan sebagai berikut: Bagaimanakah perlindungan hak keperdataan anak luar kawin dalam pandangan ilmu hukum berparadigma Pancasila?

\section{Pembatasan Permasalahan}

Hak keperdataan mencakup beberapa bidang seperti: hak pemeliharaan, hak pendidikan, hak untuk memakai nama keluarga, hak untuk didampingi oleh orangtuanya di dalam maupun di luar hukum, serta hak waris. Karena keterbatasan ruang, dalam tulisan ini Penulis hanya membahas tentang hak atas pemeliharaan dan pendidikan dari anak luar kawin.

\section{Analisis}

\section{Hukum Perkawinan dalam Paradigma Pancasila}

Dalam sistem hukum Indonesia, perkawinan diatur dalam Undangundang Nomor 1 Tahun 1974 tentang Perkawinan. Wantjik Saleh (1980: 3) menyebutkan bahwa adanya suatu Undang-Undang yang bersifat nasional mutlak perlu bagi Negara dan Bangsa seperti Indonesia, yang masyarakatnya terdiri dari berbagai macam suku bangsa dan golongan penduduk. Undang-Undang Perkawinan ini meletakkan asas-asas hukum Perkawinan Nasional sekaligus menampung prinsipprinsip dan memberikan landasan hukum perkawinan yang selama ini menjadi pegangan dan telah berlaku bagi berbagai golongan masyarakat. Hazairin (Saleh, Wantjik K., 198: 3). menamakan undang-undang ini sebagai suatu unifikasi yang unik dengan menghormati secara penuh adanya variasi berdasarkan agama dan kepercayaan yang berKetuhanan Yang Maha Esa.

Pasal 1 Undang-Undang Perkawinan memberikan definisi perkawinan sebagai ikatan lahir batin antara seorang pria dengan seorang wanita sebagai suami-isteri dengan tujuan membentuk keluarga (rumah tangga) yang bahagia dan kekal berdasarkan Ketuhanan Yang Maha Esa. Dengan mendasarkan pada definisi perkawinan tersebut, nampak bahwa perkawinan bukan hanya merupakan ikatan lahir semata, tetapi juga merupakan ikatan batin antara suami isteri. Tujuan dari perkawinan ini untuk membentuk keluarga atau rumah tangga yang bahagia dan kekal berdasarkan Ketuhanan Yang Maha Esa.

Dengan mendasarkan pada tujuan perkawinan tersebut, menurut Hilman Hadikusuma (2003: 22) suami isteri perlu saling membantu dan melengkapi agar masing-masing dapat mengembangkan kepribadiannya, membantu mencapai kesejahteraan spiritual dan material. Kewajiban saling membantu dan melengkapi ini berkaitan erat dengan "ikatan batin" yang ada antara suami isteri, yakni saling mencintai satu sama lain. Artinya dengan adanya ikatan batin antara suami isteri maka tujuan untuk membentuk keluarga yang bahagia lebih mudah 
diwujudkan, karena suami isteri saling mencintai, saling membantu dan melengkapi, dan saling mengembangkan kepribadian sehingga suami isteri bertumbuh semakin dewasa.

Tujuan perkawinan untuk membentuk keluarga yang bahagia berdasarkan Ketuhanan Yang Maha Esa dalam sistem masyarakat Indonesia, berkaitan erat dengan keturunan, dimana pemeliharaan dan pendidikan anak-anak menjadi hak dan kewajiban orangtua. Dengan demikian yang menjadi tujuan perkawinan menurut perundangan adalah untuk kebahagiaan suami isteri, untuk mendapatkan keturunan dan menegakkan keagamaan, dalam kesatuan keluarga yang bersifat parental /keorangtua-an (Hadikusuma, H., 2003: 22).

Tujuan perkawinan untuk memperoleh keturunan menjadi lebih sempit jika dibandingkan dengan tujuan perkawinan menurut hukum adat. Masyarakat Indonesia mengenal berbagai bentuk hubungan kekeluargaan, seperti: patrilinial, matrilineal, dan juga bilateral. Mengutip pendapat Hilman Hadikusuma (2003: 23) tujuan perkawinan bagi masyarakat hukum adat yang bersifat kekerabatan, adalah untuk mempertahankan dan meneruskan keturunan menurut garis kebapakan atau keibuan atau keibu-bapakan, untuk kebahagiaan rumah tangga keluarga/ kerabat, untuk memperoleh nilai-nilai adat budaya dan kedamaian, dan untuk mempertahankan warisan. Dalam praktek tujuan perkawinan sebagaimana dimaksudkan dalam adat kebiasaan setempat tetap dijalankan oleh masyarakat.
Hanya perkawinan yang sah yang memiliki akibat hukum. Sahnya perkawinan menurut Pasal 2 UndangUndang Perkawinan bila memenuhi dua syarat, yakni: 1) Dilakukan menurut hukum masing-masing agamanya dan kepercayaannya itu; dan 2) Dicatat menurut peraturan perundang-undangan yang berlaku. Perkawinan yang tidak dilaksanakan menurut tata tertib hukum agama (syarat pertama) dan juga tidak dicatatkan (syarat kedua) menyebabkan perkawinan tersebut tidak sah. Perkawinan yang tidak memenuhi kedua syarat perkawinan tersebut di atas, menyebabkan perkawinan tersebut tidak sah. Konsekuensi lebih lanjut, maka keturunannya disebut keturunan yang tidak sah.

Sependapat kiranya dengan pandangan S.A. Kodhi dan R. Soejadi (1988:15-16) yang menyebutkan bahwa setiap manusia di dunia ini selalu dihadapkan kepada masalahmasalah pokok yang meliputi masalah yang berhubungan dengan dirinya sendiri, dengan orang lain atau sesama, dengan alam sekelilingnya, dan dengan Tuhan penciptanya. Untuk memecahkan masalah tersebut manusia selalu berpijak pada filsafat yang dianutnya atau pandangan hidup dan pandangan dunianya yang mencerminkan seluruh hidup budayanya. Bagi bangsa Indonesia, pandangan hidup dan pandangan dunianya adalah Pancasila. Dengan demikian Pancasila akan melandasi, mendasari, menjiwai dan mengarahkan setiap sikap, tingkah laku dan perbuatannya.

Dalam persoalan perkawinan, pembentuk Undang-Undang Perkawinan menghubungkan antara 
pembentukan keluarga keluarga yang bahagia dan kekal dengan Ketuhanan Yang Maha Esa. Keterhubungan ini sesungguhnya mencerminkan sifat dasar bangsa Indonesia, yang sangat meyakini adanya "Dzat" yang Esa, Hyang Tunggal. Manusia punya jiwa, roh, sehingga segala aspek rohaniah kehidupannya dijaga sebaik-baiknya dengan nilai-nilai tertentu.

Tepatlah pendapat Driyarkara (S.A. Kodhi dan R. Soejadi, 1988:17) yang menyatakan bahwa Pancasila adalah dalil-dalil filsafat. Pancasila merupakan weltanschauung bagi Bangsa Indonesia. Dasar filsafat Pancasila yang kelima menurut Driyarkara sebagai berikut:

"Aku mengakui bahwa adaku itu ada-bersama, serba terhubung, serba tersokong, serba tergantung. Jadi adaku itu tidak sempurna, tidak atas kekuatanku sendiri. Jadi aku bukanlah sumber dari adaku. Semua hal yang terbatas, justru karena terbatasnya (sama dengan aku) tidak mungkin merupakan sumber adaku. Yang dapat merupakan sumber adaku pada akhirnya hanyalah ADA YANG MUTLAK, SANG MAHA ADA. Sang Maha Ada itu bukanlah sesuatu, melainkan Pribadi Yang Maha Sempurna. Itulah TUHAN YANG MAHA ESA. Adaku yang berupa cinta kasih itu sebetulnya adalah cinta kasih kepada Sang Maha Cinta Kasih, Sang Maha Penyayang. Dalam pikiran ini aku menemukan dasar adaku, dasar semua perbuatanku". (S.A. Kodhi dan R. Soejadi, 1988: 17).

Hal inilah yang menyebabkan bangsa Indonesia mewarnai segala aspek kehidupannya dengan memohon berkat/ridho dari Tuhan Yang Maha Esa, agar kehidupannya lebih tenang, bahagia, dan dilepaskan dari segala kesulitan dunia akhirat. Bagi bangsa Indonesia ikatan perkawinan merupakan ikatan yang "sakral". Prinsip ini dipakai dalam Undang-Undang Perkawinan, sehingga ketika hendak memasuki gerbang perkawinan seseorang seyogyanya siap secara fisik dan mental serta menetapkan syaratsyarat yang tidak mudah agar orang benar-benar memasuki gerbang perkawinan dengan pertimbangan yang matang. Karena sakral itu pula, maka Undang-Undang Perkawinan mempersulit dilakukannya perceraian.

Prinsip ini selaras dengan nilainilai yang terkandung dalam Pancasila. Nilai rohaniah yang terkandung dalam Pancasila menjadi penting karena hidup manusia memiliki jiwa, sehingga kehidupan rohaniahnya perlu dijaga sebaikbaiknya dengan nilai-nilai yang diyakini kebenarannya, yakni nilai etik (moral) dan nilai religious (keTuhanan). Inilah kiranya yang menyebabkan penghormatan terhadap lembaga perkawinan. J. Satrio (2000: 6) berpendapat bahwa lembaga perkawinan perlu dilindungi sebagai lembaga yang suci. Pemberian sanki berupa perbedaan status antara anak sah dan anak luar kawin diharapkan dapat mengurangi munculnya anak luar kawin. Hanya yang kemudian menjadi persoalan dalam hal anak luar kawin adalah perbedaan status yang diterapkan oleh pembentuk undang-undang justru merupakan diskriminasi yang merugikan "anak-anak yang tidak berdosa", yang terpaksa harus menanggung stigma sebagai akibat perbuatan orangtuanya. Diskriminasi ini menjadi tidak sesuai dengan 
semangat Sila ke-2 Pancasila, dimana Pancasila menghendaki penghormatan atas persamaan di hadapan hukum dan hak-hak asasi manusia.

\section{Anak Luar Kawin}

Witanto DY. (2012: 12) menyebutkan bahwa secara fitrah alamiah, tidak ada sedikit pun perbedaan antara anak yang dilahirkan dari suatu perkawinan yang sah dengan anak yang lahir di luar perkawinan. Keduanya merupakan subjek hukum yang seharusnya dilindungi oleh Negara dan undang-undang. Menurut pandangan agama, tidak ada satu agamapun yang menganut pandangan dosa keturunan, sehingga stigma tentang anak luar kawin yang sering disebut sebagai "anak haram jadah", "anak kampang", "anak sumbang", "anak kowar", "anak astral" dan sebagainya harus disingkirkan dari identitas yang selama ini melekat pada diri mereka, dan perlahan-lahan masyarakat harus dapat memahami bahwa yang membedakan mereka dengan anak-anak lain pada umumnya hanyalah nasib dan takdir semata. Perbuatan zina dan haram yang dilakukan oleh orangtuanya tidak bisa memberikan stigma haram bagi si anak. Anak yang lahir dari sebab hubungan apapun harus tetap dipandang sebagai anak yang suci dan terlepas dari dosa yang dilakukan oleh orangtuanya, dan semestinya juga dihadapan hukum ia harus mendapatkan hak dan kedudukan yang seimbang dengan anak-anak sah lainnya.

Penolakan terhadap anak luar kawin oleh masyarakat memang berbeda antara masyarakat yang satu dengan masyarakat yang lain.
Menurut D.Y. Witanto (2012: 13) di lingkungan masyarakat tertentu diyakini jika terdapat "anak haram jadah" tinggal di lingkungan mereka, maka akan timbul malapetaka bagi lingkungan di sekitarnya, sehingga anak dan ibu diusir dari tempat itu dengan alasan agar warga masyarakat yang lain terhindar dari kutukan.

Selain diskriminasi secara sosial kemasyarakatan, anak luar kawin juga mengalami diskriminasi secara hukum.

Undang-undang membedakan anak menjadi anak sah dan anak luar kawin, meskipun undang-undang tidak memberikan definisi mengenai apa yang dimaksud dengan anak luar kawin.

Definisi anak sah dapat ditemukan pada Pasal 250 KUHPerdata yang menyebutkan: "Tiap-tiap anak yang dilahirkan atau ditumbuhkan sepanjang perkawinan, memperoleh si suami sebagai bapaknya". Undang-Undang Perkawinan memberikan pengertian anak sah dalam Pasal Pasal 42 yang menyebutkan bahwa: "Anak yang sah adalah anak yang dilahirkan dalam atau sebagai akibat perkawinan yang sah". Dengan demikian secara $a$ contrario anak luar kawin adalah: 1). anak yang lahir di luar perkawinan yang sah ataupun 2). anak yang lahir bukan sebagai akibat perkawinan yang sah.

J. Satrio (2000: 5) menyebutkan bahwa anak luar kawin sebagai "keturunan yang tidak sah." Keturunan yang tidak sah ini diberikan definisi sebagai keturunan yang tidak didasarkan atas suatu perkawinan (yang sah). Menurut J. Satrio (2000: 18) baik KUHPerdata maupun Undang-Undang Perkawinan berlaku prinsip bahwa keturunan 
yang sah didasarkan atas suatu perkawinan yang sah. Prinsip ini tidak hanya dikenal dalam sistem hukum Indonesia, di beberapa Negara lain memakai ukuran yang sama, seperti misalnya dalam hukum di Amerika Serikat, Harry D. Krause (J. Satrio, 2000: 18) menyebutkan bahwa: "Legitimacy is defined primarily by reference to the marital status of the child's parents".

Pembedaan anak menjadi anak sah dan anak luar kawin membawa konsekuensi yang berbeda terhadap hak-hak keperdataan anak. Anak sah boleh menikmati berbagai "hak istimewa" atas pendidikan dan pemeliharaan, hak waris, serta berbagai hak dan kewajiban yang timbul karena adanya hubungan darah. Sedangkan anak luar kawin hampir tidak memiliki hak apapun. Seandainyapun si anak luar kawin ini mendapatkan hak, maka hal itu hanya terjadi setelah bapak biologisnya melakukan "pengakuan" atas dirinya. Pengakuan oleh bapak biologis inilah yang menimbulkan hubungan keperdataan antara si anak dengan bapak biologisnya. Namun pengakuan ini tak pernah mampu menyebabkan kedudukan si anak luar kawin sama seperti halnya anak sah. Setelah pengakuan yang dilakukan bapak biologisnya si anak luar kawin boleh menikmati beberapa hak keperdataan. Perbedaan hak inilah yang merupakan diskriminasi secara hukum.

\section{Hak Keperdataan sebagai Hak Asasi Anak dalam Sistem Hukum Indonesia yang Berparadigma Pancasila}

Di dalam sistem hukum Indonesia, setiap manusia diakui sebagai subjek hukum. Pasal 27 ayat
(1) Undang-Undang Dasar 1945 menyebutkan: "Segala warga Negara bersamaan kedudukannya di dalam hukum dan pemerintahan dan wajib menjunjung hukum dan pemerintahan itu dengan tidak ada kecualinya".

Pesan yang disampaikan oleh Pasal 27 ayat (1) UUD1945 selaras dengan Pasal 2 KUHPerdata yang menyebutkan: "Anak yang ada dalam kandungan seorang perempuan, dianggap sebagai telah dilahirkan, bilamana juga kepentingan si anak menghendakinya." Inti dari Pasal 2 ayat (1) KUHPerdata adalah pengakuan tentang status anak sebagai subjek hukum. Dalam kondisi tertentu, anak yang masih berada dalam kandungan ibunya telah diakui hak-hak subjektifnya apabila kepentingannya menghendaki, yakni dalam kondisi khusus: pewarisan, hibah, dan perwalian. Sebagai subjek hukum, anak-anak berhak menyandang hak keperdataan. Adapun yang dimaksud dengan "hak keperdataan anak" adalah hak-hak di bidang hukum perdata yang dimiliki oleh seseorang anak, meliputi: hak atas pemeliharaan, hak untuk diwakili dalam melakukan perbuatan hukum dan hak mewaris.

Anak sah berhak mendapatkan hak keperdataan secara penuh dari bapak maupun ibunya, sedangkan anak luar kawin hanya berhak menikmati hak keperdataan dari ibunya dan/atau keluarga ibunya, kecuali bila bapak biologisnya telah melakukan pengakuan atau dengan keputusan hakim si anak luar kawin dinyatakan memiliki hubungan darah dengan bapak biologisnya.

\section{Apakah hak keperdataan anak merupakan hak asasi anak?}


Negara Indonesia memberikan jaminan yang kuat terhadap pengakuan hak asasi anak. Sistem pengakuan hak asasi anak di Indonesia berkelindan amat kuat, yakni perpaduan dari: Alinea I Pembukaan UUD1945, Sila Kedua Pancasila, Pasal 27 ayat (1), Pasal 28 huruf A, Pasal 28 huruf B ayat (1) dan (2), Pasal 28 huruf $C$ ayat (1) dan (2), Pasal 28 huruf D ayat (1) dan (4) Undang-Undang Dasar 1945. Selain pasal-pasal tersebut, masih terdapat Undang-Undang Nomor 39 Tahun 1999 tentang Hak Asasi Manusia dan Keputusan Presiden Nomor 36 Tahun 1990 tentang Pengesahan Convention on The Right of The Child.

Mengenai Hak Asasi Anak, Pasal 52 ayat (2) Undang-Undang Nomor 39 Tahun 1999 tentang Hak Asasi Manusia (UUHAM) menyebutkan bahwa hak anak adalah hak asasi manusia dan untuk kepentingannya, hak anak itu diakui dan dilindungi oleh hukum, bahkan sejak dalam kandungan. Selain itu ditetapkan bahwa setiap anak berhak atas perlindungan. Ketentuan UU HAM ini sejalan dengan ketentuan 28B ayat (2) UUD1945 yang menyebutkan: "Setiap anak berhak atas kelangsungan hidup, tumbuh, dan berkembang serta berhak atas perlindungan dari kekerasan dan diskriminasi."

Hak hidup dan hak kebebasan diakui sebagai hak azasi universal. Di atas dasar hak azasi yang pokok dan universal sifatnya itu kemudian berkembanglah hak-hak azasi lainnya yang memungkinkan manusia hidup layak sebagai manusia di dalam masyarakat, dengan menggunakan kemampuan dan kemungkinnan yang menjadi alat perlengkapannya. Kuntjoro Purbopranoto (Dardji
Darmodiharjo, dkk. 1979: 267) dalam tulisan yang berjudul "Hak-hak Azasi Manusia dalam Pancasila" menyatakan bahwa dalam hak atas kebebasan yang disebut liberty itu termasuk pula hak untuk memperoleh kemajuan hidup dan pendidikan.

Pasal 53 UU HAM menyebutkan:

(1) Setiap anak sejak dalam kandungan, berhak untuk hidup, mempertahankan hidup, dan meningkatkan taraf kehidupannya.

(2) Setiap anak sejak kelahirannya, berhak atas suatu nama dan status kewarganegaraan.

Hak anak sebagai Hak Asasi Manusia dilindungi oleh kesepakatan masyarakat Internasional yang dikodifikasikan dalam Konvensi HakHak Anak Perserikatan BangsaBangsa (United Nations Convention on the Rights of the Child). Konvensi Hak Anak menjadi konvensi internasional yang mengatur hak-hak sipil, politik, ekonomi dan kultural anak-anak. Di Indonesia, Konvensi Hak Anak ini telah diratifikasi dengan Keputusan Presiden Nomor 36 tahun 1990 tentang Pengesahan Convention on the Rights of the Child.

Konvensi Hak Anak terdiri dari 54 pasal yang berdasarkan materi hukumnya mengatur mengenai hakhak anak dan mekanisme implementasinya oleh Negara peserta yang meratifikasi Konvensi Hak Anak. Materi tersebut dapat dikelompokkan menjadi empat kategori, yaitu:

1. Hak atas kelangsungan hidup (Survival Rights)

Hak atas kelangsungan hidup meliputi hak untuk melestarikan hidup dan mempertahankan hidup serta kesehatan dan perawatan yang baik. 
2. Hak atas Perlindungan (Protection Rights)

Hak atas perlindungan meliputi perlindungan dan diskriminasi, tindak kekerasan dan keterlantaran.

3. Hak atas Perkembangan

(Development Rights)

Hak untuk tumbuh dan berkembang meliputi pendidikan baik formal maupun non-formal serta mencapai perkembangan fisik, mental spiritual, moral, dan sosial.

4. Hak untuk Berpartisipasi (Participation Rights)

Hak untuk berpartisipasi meliputi hak untuk menyatakan pendapat dalam segala hal yang mempengaruhi anak (the rights of a child to express her/his views in all matters affecting that child).

Dari ke-54 pasal Konvensi Hak Anak dapat dikelompokkan ke dalam 10 hak anak sebagai berikut:

1. Hak untuk Bermain.

2. Hak untuk mendapatkan Pendidikan.

3. Hak untuk mendapatkan Perlindungan.

4. Hak untuk mendapatkan Nama (Identitas).

5. Hak untuk mendapatkan status Kebangsaan.

6. Hak untuk mendapatkan Makanan.

7. Hak untuk mendapatkan akses Kesehatan.

8. Hak untuk mendapatkan Rekreasi.

9. Hak untuk mendapatkan Kesamaan.

10. Hak untuk memiliki Peran dalam Pembangunan.

Kesepuluh hak tersebut disepakati sebagai Hak Asasi Anak, dimana negara-negara peserta
Konvensi dan Negara yang telah meratifikasi Konvensi Hak Anak wajib untuk mengusahakan terpenuhi dan terlindunginya hak asasi anak tersebut.

Dalam konteks kehidupan kenegaraan di Indonesia, pengakuan atas Hak Asasi Anak sebenarnya telah dikenal lama dalam nilai-nilai yang terkandung dalam Pancasila. Nilainilai yang terkandung dalam pengakuan atas hak keperdataan anak sebagai bagian dari hak azasi anak adalah nilai materiil dari Pancasila. Bila selama ini disepakati bahwa hak keperdataan anak berisikan antara lain hak atas pemeliharaan dan pendidikan, serta hak atas tumbuh kembang, maka hakhak tersebut sesungguhnya telah terjamin dalam sistem kenegaraan Indonesia yang berdasarkan Pancasila. Hak pemeliharaan anak pada dasarnya berisikan pemenuhan kebutuhan materiil (duniawi) anak yang diperlukan untuk kehidupannya. Dengan demikian dapat dikatakan bahwa dalam hak pemeliharaan anak terkandung nilai materiil Pancasila, yakni segala sesuatu yang berguna bagi unsur kemanusiaan (duniawi) manusia. Sedangkan hak atas pendidikan berkaitan dengan nilai kerohanian, yaitu segala sesuatu yang berguna bagi rohaniah manusia, karena pendidikan berkaitan dengan pembentukan karakter/kejiwaan seseorang. Dalam pendidikan seseorang belajar untuk mencari dan mencapai kedewasaan sebagai manusia yang seutuhnya. Sedangkan dalam hak atas tumbuh kembang anak terkandung nilai materiil sekaligus pula nilai kerohanian, karena dalam tumbuh kembang anak untuk mencapai kedewasaan yang 
sempurna, tak dapatlah dilepaskan dari yaitu segala sesuatu yang berguna bagi unsur kemanusiaan seorang anak, termasuk pada anak luar kawin. Nilai religious sebagai unsur dari Nilai kerohanian/Nilai Ketuhanan, yang tertinggi dan mutlak. Nilai religious ini bersumber pada kepercayaan/keyakinan manusia akan adanya Tuhan Yang Maha Esa dalam kehidupan manusia.

Kewajiban untuk memenuhi hak asasi anak yang diamanatkan oleh KHA sebenarnya bukan semata-mata tugas Negara, tetapi dalam beberapa aspek kewajiban itu juga melekat pada orangtua, keluarga, serta masyarakat. Pemerintah dalam hal ini lebih pada posisi pengambil kebijakan, mengawasi penegakannya, serta memfasilitasi agar hak asasi anak tersebut terjamin pemenuhannya.

\section{Ide des Rechts Theory dalam Pengakuan Hak Pemeliharaan, Hak atas pendidikan, dan Hak Tumbuh Kembang Anak Luar Kawin}

Mengutip pendapat Radbruch, bahwa putusan hakim yang ideal ialah apabila mengandung unsurunsur gerechtigkeit (keadilan), zweeckmassigkeit (kemanfaatan), dan rechtssicherkeit (kepastian hukum). Suatu putusan hakim harus adil, tetapi harus pula bermanfaat bagi yang bersangkutan maupun bagi masyarakat, dan terjamin kepastian hukumnya. Dalam hal terjadi konflik antara keadilan dan kepastian hukum, maka hakim berdasarkan freies ermessen-nya dapat memilih keadilan dengan mengabaikan kepastian hukum sepanjang tidak bertentangan dengan kepentingan umum atau Negara. (Mertokusumo,
S., 2012: 23-24). Demikian pula ketika menyusun sebuah norma hukum, maka seyogyanya pembentuk undang-undang memperhatikan unsur: keadilan, kemanfaatan, dan kepastian hukum. Hal ini sesuai dengan tujuan hukum, yakni memberikan perlindungan bagi sebanyak mungkin anggota masyarakat.

Dalam persoalan hak keperdataan anak luar kawin, pengakuan (oleh hukum) khususnya hak atas pemeliharaan dan pendidikan, serta hak untuk tumbuh kembang akan memberikan rasa keadilan (gerechtigkeit) bagi anak luar kawin dan ibunya. Rasa keadilan ini selaras dengan pengakuan hukum bahwa setiap orang sama dihadapan hukum, karena selama ini ibu dan anak luar kawin ini dalam praktek sulit untuk mendapatkan pengakuan oleh bapak biologisnya. Pengakuan atas hak keperdataan bagi anak luar kawin juga akan membawa manfaat bagi anak luar kawin. Dengan diakuinya hak keperdataan si anak luar kawin -setelah menempuh prosedur pembuktian tertentu- akan membantu kehidupan si anak baik secara fisik maupun secara psikis. Perasaan bahwa mereka adalah anak yang "sempurna" karena memiliki bapak daan ibu, akan baik bagi perkembangan psikis serta membuang stigma yang diberikan oleh masyarakat terhadap mereka. Pengakuan hak keperdataan oleh hukum juga dipastikan akan memberikan kepastian hukum (rechtssicherkeit) bagi anak luar kawin tersebut. 


\section{Simpulan}

Berdasarkan uraian tersebut di atas dapat diambil kesimpulan sebagai berikut:

1. Anak luar kawin sebagai subjek hukum di dalam masyarakat perlu diakui hak-haknya, terutama hak atas pemeliharaan dan pendidikan, serta hak untuk tumbuh kembang secara sempurna. Di dalam hak pemeliharaan anak terkandung nilai materiil Pancasila. Hak atas pendidikan berkaitan dengan nilai kerohanian, yaitu segala sesuatu yang berguna bagi perkembangan rohani anak luar kawin. Sedangkan dalam hak atas tumbuh kembang anak terkandung nilai materiil sekaligus nilai kerohanian. Hak atas pemeliharaan dan pendidikan serta hak untuk tumbuh kembang ini merupakan Hak Azasi Anak yang telah diratifikasi dengan Keputusan Presiden No. 36 Tahun 1990 tentang Pengesahan Convention on the Rights of the Child.

2. Pengakuan secara normatif terhadap hak anak luar kawin perlu dilakukan dalam sistem hukum Indonesia agar tidak lagi terjadi diskriminasi terhadap anak luar kawin. Pengakuan secara normatif terhadap hak atas pemeliharaan dan pendidikan anak luar kawin akan memberikan keadilan, kemanfaatan, serta kepastian hukum untuk menjamin tumbuh kembangnya secara sempurna.

\section{Daftar Pustaka}

Bakri, Noor MS., 1994, Pancasila Yuridis Kenegaraan, Edisi ketiga cetakan pertama, Yogyakarta: Liberty.

Darmodiharjo, Dardji (dkk), 1979, Santiaji Pancasila, Surabaya: Usaha Nasional.

Hadikusuma, Hilman., 1980, Hukum Perkawinan Indonesia, Jakarta: Ghalia Indonesia.

---------, 2003, Hukum Perkawinan Indonesia Menurut: Perundangan, Hukum Adat, Hukum Agama, Cetakan kedua, Jakarta: Mandar Maju.

Mertokusumo, Sudikno., 2012, Teori Hukum, Yogyakarta: Cahaya Atma Pustaka.

Pranarka, Kuntjoro., 1985, Sejarah Pemikiran tentang Pancasila, Cetakan pertama, Jakarta: CSIS.

Satrio, J., 2000, Hukum Keluarga tentang Kedudukan Anak dalam Undang-Undang, Cetakan pertama, Bandung: Citra Aditya.

S.A. Kodhi, S.A., dan Soejadi, R., 1988, Filsafat, Ideologi dan Wawasan Bangsa Indonesia, Yogyakarta: Penerbitan Universitas Atma Jaya.

Witanto, D.Y., 2012, Hukum Keluarga, Hak dan Kedudukan Anak Luar Kawin Pasca Keluarnya Putusan MK tentang Uji Materiil UU Perkawinan, Cetakan Pertama, Jakarta: Prestasi Pustaka. 